\title{
University-School Scenarios and Voices from Classrooms. Rethinking Collaboration within the Framework of an Interuniversity Project
}

\author{
Elia Fernández-Díaz ${ }^{1}$ (D) Prudencia Gutiérrez Esteban² ${ }^{(0)}$ and Lorea Fernández Olaskoaga ${ }^{3}$ (D) \\ ${ }^{1}$ Department of Education, University of Cantabria, Spain \\ ${ }^{2}$ Department of Educational Sciences, University of Extremadura, Spain \\ ${ }^{3}$ Departamento de Didáctica y Organización Escolar, University of the Basque Country, Spain
}



Received 28-11-2018

Revised 07-01-2019

Accepted 07-05-2019

Published 15-07-2019

Corresponding Author

Elia Fernández-Díaz,

eliamaria.fernandez@unican.es

Facultad de Educación, Avd. Los Castros 52, 39005 Santander

DOI https://doi.org/10.7821/

naer.2019.7.372

Pages: 79-95

Distributed under

Creative Commons CC BY 4.0

Copyright: (C) NAER Journal of New Approaches in Educational Research 2019

\section{OPEN ACCESS}

\section{ABSTRACT}

This work presents the analysis of a proposal designed in the field of initial teacher training, the aim of which is to promote the presence of schools in a university context. With the objective of enabling students to experience practical and reflective learning, we have designed a process of interuniversity collaboration focused on horizontally developing interaction and the generation of knowledge. The deconstruction of the process, based on a narrative approach, has allowed us to open a space to reflect on the actions that encourage participation and exchange between undergraduate students from different universities and promote links with schools. The results show the transformations of the protagonists of the experience and of those who participated indirectly, redefining personal stories in the context of collaborative work and the improvement of our professional development. It also shows the implications of an interuniversity project, recounting the richness inherent in the mixture of geographical and cultural contexts involved. The dilemmas and critical incidents allow us to guide the introduction of improvements in the next cycle of collaboration.

\section{Keywords COLLABORATION, PARTICIPATORY RESEARCH, PRE-SERVICE TEACHER EDUCATION, TRANSFORMATION, SCHOOLS}

\section{INTRODUCTION}

The research presented here constitutes the second stage of an interuniversity project of collaboration, which began in 2012, funded by the Educational Technology University Network in Spain. Teachers from different Spanish universities (the Basque Country, Extremadura and Cantabria), whose field of knowledge is related to educational technology and teaching in Primary Education, have participated in this interuniversity project involving university students in the design of alternative learning environments.

Our initial approach focused on the analysis of the process of interuniversity collaboration, which is technologically mediated to reflect and transform our practice and improve 
student learning. We began to stimulate the exchange of experiences between participating classrooms through the design of agoras or work assemblies, whose purpose was to discuss and allow the confrontation of perspectives with regard to the role of teacher researcher (Fernández-Díaz, Fernández-Olaskoaga, \& Gutiérrez-Esteban, 2017) . To this end, spaces were created in which students could collaborate by sharing reflections on the issues surrounding educational practice as well as making decisions on possible alternatives for transformation. Thus, we started working together to improve the dynamics of knowledge reconstruction and began opening our own classrooms beyond the university context.

From the analysis of the results of the first stage we were able to identify the main findings and challenges posed by this interuniversity project. We had not only managed to create a working environment which enabled students to exchange experiences and rethink the role of the teacher, but we had also shared reflections on our university teaching practices and transformed the traditionally isolated scenarios in which initial training is usually developed. Nevertheless, we detected several difficulties during the development of the process. On the one hand, we found an excessive use of technological tools (Google Sites, Groups, Twitter, Youtube, Blogger) which, far from promoting improvement, contributed to dispersing our own process of reflection and the student interaction. On the other hand, we became aware of the need to improve our collaboration project, promoting links between different contexts and reflecting on inherent participatory dilemmas. In this way, we intend to move towards a new model of university teaching capable of questioning the role of the teacher in the university context and the inertias that prevent us from cognitively agitating our students, maintaining institutionalized practices. In this sense, we will also explain the controversies that arise as we embrace activism and face the urgent need to abandon our comfort zones (Brown, 2008; Forés, Sanchez-Valero, \& Sancho, 2015).

In the Spanish university context, the adoption of common guidelines within the framework of the European Higher Education Area has resulted in the modification of the curricula in Teacher Education Degrees in order to achieve the professionalisation and improvement of initial teacher training. There has been an attempt to redirect attention towards students, with the objective of training teachers capable of dealing with problems and responding to the needs of today's society, increasing and facilitating the acquisition of skills, far removed from the mere transmission of content (COM, 2007). Along the same lines, the length and quality of the practicum period has been increased to provide students with basic training, complementing academic learning with experience in schools. However, structural changes in search of transversality or links with the remaining subjects have not been implemented; the work experience practicum continues to appear as an independent subject in the curricula, without there being adequate interrelation between theory and educational practice (Darling-Hammond et al., 2005; De Oliveira \& Gallardo-Echenique, 2015; Rice, 2002; Sutherland, Howard, \& Markauskaite, 2010).

Together with the division of knowledge perpetuated by disconnection and hierarchization between subjects as a consequence of the existing training model (Schiro, 2008), recent studies on the construction of teacher identity and reflection processes on action in initial 
teacher training (Zeichner \& Conklin, 2008) continue to demand the need to promote the research role of students in the curricula.

Based on the scenario described above, we consolidated our interuniversity collaboration project and began a new course of action in 2014, focused on increasing the generation of collaboration scenarios between universities and schools. In this trajectory, which we will describe in the following section, we promoted the presence of schools in the university context and worked gradually to weave the underlying focus of the process of inquiry, as we reflected on the meaning of the different narratives, present in the context of our work, as mediating tools of improvement.

\section{THEORETICAL PERSPECTIVE}

Given this new situation, the review of experiences of facilitation and/or accompaniment of the university in the processes of educational and social change represent a turning point both in the basis of our interuniversity model of collaboration and commitment to contributing to the provocation and questioning of what is institutionalised. Our way of collaborating is based on three pillars: the resonances identified in other interuniversity practices characterised by the use of narrative; the prioritisation of the horizontal nature of collaborative relationships with other agents; and the search for disruption in university life. A detailed explanation of the three pillars is given below.

Firstly, we followed in the footsteps of other research groups whose contributions have helped to promote the role of narratives in understanding the findings and limitations of opening university classrooms for the exchange of experiences with the objective of increasing the joint reconstruction of knowledge. In this regard, we have identified interuniversity collaboration experiences that encourage alternative teacher training models by promoting the use of strategies that favour the construction of transformative professional identities (Clandinin, 2013; Clandinin \& Connelly, 1991; Cortés, Rivas, \& Leite, 2016; Rivas, 2014). We needed to rethink the spiral of cycles of planning, action, observation and reflection to ensure the integration of experiential, contextual and relational knowledge, to fully immerse ourselves in the deconstruction of a process of meeting and accompaniment of change in schools. In this new situation, we can explore how the accounts of experiences constitute mediators of understanding learning experiences, pedagogical relationships and the dilemmas that arise when we research our own practice, reconstructing ourselves and transforming our pasts together with others (Clandinin \& Connelly, 1991 2004; Sparkes \& Smith, 2008).

Secondly, we propose rethinking the process of collaboration in order to promote the presence of schools in university contexts and the role of teacher researcher during their initial training (Ng, Nicholas, \& Williams, 2010). The reconceptualisation of collaboration becomes an indispensable element in our new trajectory, in which we want the process of accompaniment to be characterised by horizontal relationships, in such a way that it makes us ethically question decision making at every stage (Fouche \& Chubb, 2015; Hansen, 2014). Likewise, this proposal of accompaniment leads us to consider the desirability of building 
this bridge between universities and schools based on recognition of the uniqueness of the participants and the establishment of links to improve the pedagogical relationship with our students (Frymier \& Houser, 2000). We promote listening to the voices from schools, going over learning stories, to fully immerse ourselves in the field of action to provide more situated, horizontal and community-based practices (Kemmis \& McTaggart, 2013; Lafuente \& Lara, 2013; Young, 2000).

Finally, the search for disruption reflects the urgency of conferring a transformative and emancipatory meaning to our educational university practice (Anderson, 2017); change structures and public policies, diversify and increase transformative itineraries providing them with greater activism (Thomson, 2015). We demand a break with the logic of continuity vs. change scarcely modified in this university context; a dormant scenario, silenced and slowed down by the policy swings of mercantilist interests which promote personal growth, mass scientific production in a convergent and alienating way, to the detriment of pedagogical relationships and the questioning of the meaning of our actions. While being conscious of the need to demand socio-political commitment in order to give meaning to our educational work, we believe that the time is right to raise the idea of allowing divergences and promoting activism (Arvanitakis \& Hornsby, 2016; McFadden \& Smeaton, 2017). This could be a break from the conventional and homogenising approach to knowledge, which is predominant in university institutions (Giroux, 2016).

\section{CONTEXT AND METHODS}

\subsection{Contextualization and meaning of the inquiry process}

We, the authors of this article, are teachers from the area of Didactics and School Organization from three Spanish universities. We participated in this study together with our university students $(\mathrm{N}=239)$ who were studying different subjects. As mentioned in the previous section, we began a new phase in 2014 (in which we are currently involved) with the objective of building bridges between universities and schools and promoting the presence of schools in university contexts. Our aim is to promote better learning by students, learning both in terms of their practice and reflection, while at the same time sharing ideas with other university students and encouraging interaction and the generation of knowledge between peers in order to improve collaboration. In this phase our main research questions were:

- Talking about breaking down university classroom barriers and expanding into other contexts: How could we generate knowledge among university students, university teachers and the schools involved through the research project?

- Related to the pedagogical relationship and disruptions: Which tools and strategies could be used to promote the role of the university students as researchers? And how can we critically commit them to promote activism?

Considering the proposal described above, we began by establishing relationships with schools in order to invite them to participate in different workshops on multiple intelli- 
gences (Gardner, 1983) which would be designed, developed and evaluated by university students. It was an attempt initially developed in the University of the Basque Country arena, as part of a curricular and interdisciplinary piece of work shared with other subjects in the same semester. This context was also suitable for students from the University of Extremadura.

The design of these activities was organised considering their curricular contextualisation, allowing for a process of self-assessment through virtual shared reflection about the experience developed. In addition, a guided tour around the building was planned so that the school students could get to know the space where future teachers study. To optimise the meeting a significant point was organised where university and school students, together with school teachers and university teachers, could share a relaxed, informal meeting over lunch to encourage the exchange of opinions on the experiences.

With the aim of exchanging the development processes of the workshops, we carried out a previous and asynchronous collaboration between our university students. Firstly, a series of videos was produced by the University of Extremadura, which demonstrated the relationship between the skills and contents of the legally established curriculum for Primary Education students. The proposal was to create audiovisual shorts in which knowledge is condensed using images and text lasting just a few minutes each and which, in addition to skills and contents, also incorporated some intelligence defined by Gardner. After making these audiovisual shorts and sharing them digitally, using Google Drive, the students from the University of the Basque Country had to assess issues such as the following: how to adapt audiovisual didactic material to the characteristics of the students, the selection of contents, the visual value of the didactic material generated, the level of linkage between the topics included in the audiovisual short and social problems. They were also given the task of proposing appropriate improvements.

This exchange enabled the subsequent improvement of the design and development of the workshops for Primary school students. From the perspective of two different universities we are contemplating the possibility of carrying out the same activity in parallel, which would include the implementation of the theory used in the subjects, in a practice involving Primary students. Furthermore, the university-school meetings would be developed based on this common bond achieved between two subjects with different content.

\subsection{Data generation and collection; data analysis}

In this article, we will focus on highlighting the changes introduced in the phase under analysis in order to use narrative inquiry methodology (Cochram-Smith \& Little, 1993).

During the previous phase the need for a macro-level feedback from students from different universities was identified. Thus, several exchanges between students from the three universities were planned; these took place in a relatively short time and the actions and/or activities were organised together or at least, shared the learning objectives. Prior to data collection, we specified and defined the collaborative context to be documented. Contacts were established with the schools for the exchange experiences, the workshops were designed and implemented and an evaluation and reflection on the development of 
the experience with different agents (university students, school students, school teachers and the university teachers involved) was carried out.

With regard to information collection techniques (participant observations, diaries, discussion groups, interviews, and questionnaires), it is important to highlight the modification of the initial design which was technologically mediated to host face to face techniques in data collection on student activity: face to face discussion groups were introduced, together with e-research, which was initially carried out in relation to observation of the production of blogs and the rest of the multimedia activities. On the other hand, narrative techniques and interviews with external facilitators were used to complement our main tools (diaries and discussion groups) and overcome difficulties in the compilation of data in a process initially characterised by the dispersion of tools.
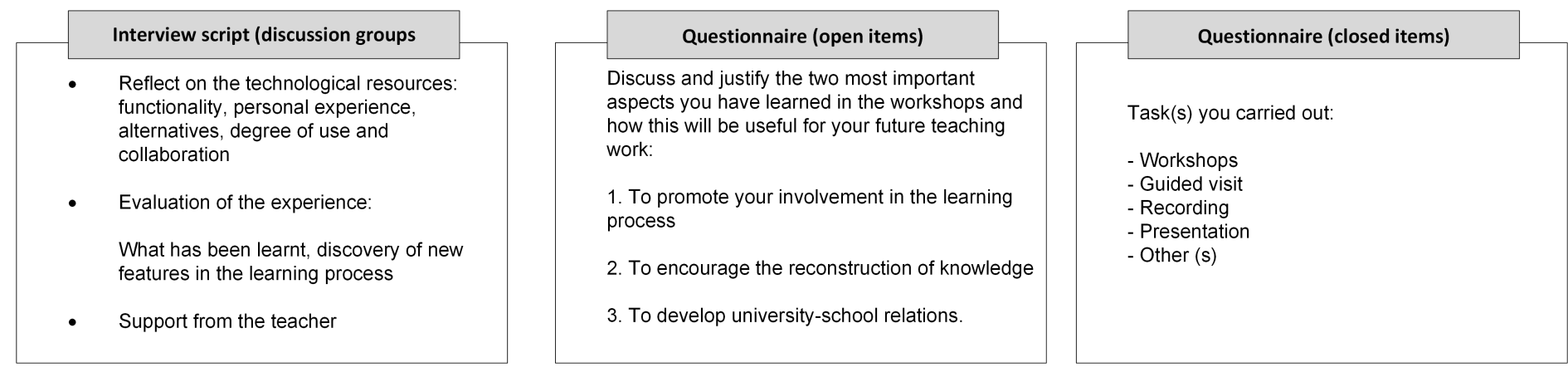

Figure 1 Summary of data collection

As far as the analysis of data is concerned, a process of reflection has been carried out in relation to dimensions (Miles \& Huberman, 1994) that have arisen from the implementation of the process of collaboration in an attempt to respond to the issues that have guided the process of inquiry and integrate the dilemmas that have emerged from the analysis of voices from classrooms. The dimensions of the analysis used were developed following in the footsteps of other work focused on exploring the transformational potential of narratives (Rivas et al., 2016). These dimensions are:

- The redefinition of our teaching work in the approach to other contexts.

- The pedagogical relationships at university and at school.

- Transformative action within the university context, taking into account resonances, dilemmas and new training models.

According to Patton and Parker (2017) these dimensions were identified by using inductively derived categories from acquired data and based on relevant former studies from the review of literature. All the data sources (Figure 1) were analysed using the same methods. Therefore, an open and axial coding (Corbin \& Strauss, 2008) was carried out in order to interpret data that allows the identification of dimensions that represent participants' views and stories of their participation and contributions to these experiences. During the coding 
stage, all transcript information was read several times. Moreover, in every source of data, keynote sentences were underlined, and significant thoughts, beliefs and ideas were linked to the dimensions identified afterwards.

At the same time, the stories themselves, highlighted by participants, have been respected and discussed within the context of previous indicators from the literature. "Therefore, each narrative contains the mark of authorship shaped by the experience itself and each collaborator's way of sharing it, as well as each researcher's own style" (HernándezHernández \& Sancho, 2017, p. 22). A process of shared analysis (technologically mediated by using shared text documents but also videoconference work sessions to exchange views about data analysis, interpretation and discussion of results), has been carried out by the university teachers. As a result, the methodology used, is characterised by being open, emergent, flexible, and in continuous development (Margalef \& Pareja, 2008). We do not understand these dimensions as "the only possibility of analysis, nor do we think of them as closed categories" (Sancho \& Padilla, 2016, p. 59). Thus, it has been possible to identify similarities and differences, but also findings or divergences, which lead us to deepen our reflection on the transformation of teaching scenarios in the initial teacher training arena, fostering spaces that break down barriers and enhance the construction of pedagogical relationships.

A summary of the methodological design is shown in Figure 2.
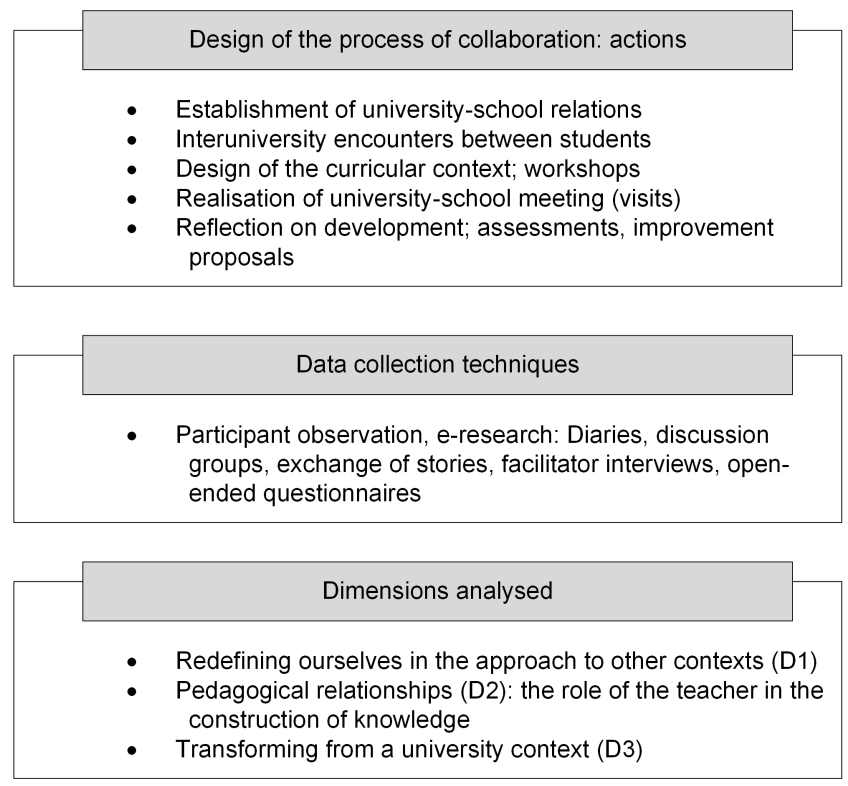

Figure 2 Summary of the methodological design

\section{RESULTS: UNRAVELLING THE STORY OF COLLABORATION}

In the following section, we will pay particular attention to the analysis of the results, organised around the dimensions that emerge from the deconstruction of the stories, based on 
the research questions described earlier. The participants are identified as following: UT (university teacher); school teacher (ST) and university students (US).

\subsection{Redefining ourselves in the approach to other contexts}

The construction of the stories about the developed actions and related events plays a crucial role in the establishment of university-school relations. In this first moment, listening to the voices from the school and focusing on getting to know its history and the context in which it exists helps us to unlearn models originating from pre-established rigid formulas. We prioritise the generation of links in which relationships characterised by their horizontality guarantee joint decision making. Thus, we become aware of a negotiated process in which both parties, the university and the school, share the desire to promote a meeting, which appeals to both the Primary students and the university students. As teachers, we also share the need to generate a working environment without institutional ties or limits, which also welcomes the recognition of participants' desires and individual characteristics.

"A teacher who was tired of the limits imposed by the time shown on the clock"

Without a doubt, his opinion is what I value most highly because it lets me see what he wants for his students, really active students who respond well to trips out. He told me that it is important for there to be a guided tour of the spaces in the school and that in this way there could be a talk (...) He also told me that he didn't want to be at the mercy of time, that it would be interesting to have breathing space between activities, that if the experience lasted for more than 2 hours fine, and if it went on for less time that was ok too. He said it would be very interesting to work in spaces, where you can rotate from one to another without obligation. (UT1_D1; stories, 2015).

On the other hand, getting involved in a university-school process of collaboration requires a rethinking of the pillars of university activity, the need to break away from this inertia which leads us to develop learning situations without prioritising reflection on the role of the university in the transformation of school structures and social reality. During the period in which relationships are established for the purpose of beginning the process of collaboration, the stories of the teacher from the school in Extremadura allowed us to understand the lives of excluded students and the urgent need to react in the face of the inexorability of these students' destiny, a future defined by the social-economic deprivation in the neighbourhoods where schools are located.

"I think this is the beginning of a good friendship"

In general, the social situation could be considered as disadvantaged, very disadvantaged, made worse by the recession (...). For the most part they love games involving activities, experiments, activities related to art, activities in which they feel like participants, actors, a bit like protagonists. Their attention span is quite 
limited when it comes to verbal explanations; they need short activities to motivate them. They can get there with courage and effort they can, because it encourages them all to get to the Faculty (...). You need to understand that the expectations they have for themselves are very low. (ST 1_ D1; interview, 2015).

The deconstruction of the stories revealed that school students need role models to follow (US), to continue their studies and believe in education as a way of escaping of their situation and transforming their lives. This is important for them to allow them to have the same opportunities as any other person to choose their own destiny.

\subsection{Rethinking the role of the teacher in the construction of knowledge}

One of our fundamental concerns relates to the need to increase student involvement in the process of teaching-learning in order to be able to overcome a directive classroom management model. Thus, we considered the exploration of the modifications of our relationship with students within the context of university-school collaboration to be crucially relevant, offering opportunities for university students to become involved in the design, development, monitoring and evaluation of the workshops they carried out in the school visits to the university in a situated and functional way.

However, reflection on the practice allows us to identify the co-existence of some situations in which a certain hierarchy continues to be evident, leadership, based on tradition, which complicates the reconstruction of knowledge in university classrooms, the establishment of links and the generation of an optimal working environment.

Narrating in this process helps to raise awareness of the need to rethink routines and roles to encourage critical thinking and interaction in the classroom with regard to reflection on pedagogical relationships.

"They weren't allowed to say... I don't know"

We were going to have a talk about methodology in primary school classrooms and the general reaction was silence (...) They have asked questions to promote participation but it's difficult... the feeling is the same, that it is just one student who contributes and talks. They are forbidden to use the expression "I don't know", which they use a lot!!! Critical thinking is a pending subject and we need to work on it (...) Today's class has been a clear example in which a mediator, instead of mediating, ends up leading...I think my role hasn't changed at all and neither has that of the students (UT1_D2; stories, 2015)

\subsection{Promoting activism: the role of the university in social transformation}

Returning to the problems described earlier, related to the deprived context of collaboration. Reflection on the design of workshops, carried out together in the discussion forums by the 
university teachers allows us to make negotiated decisions about issues to work on in order to highlight social problems that hinder the achievement of education in terms of equality.

Given that one of the distinguishing features on our new path to collaboration was closely linked to the need to generate disruptive actions in the university context, we consider raising awareness in students to be a priority. This enables them to contribute to the transformation of socio-educational reality and carry out actions that encourage the eradication of excluding circumstances. Therefore, we try to prioritise situations that promote the construction of a teacher identity that makes teaching committed to the improvement of circumstances surrounding the individual possible, in such a way that students can develop their life project and participate actively and critically in their social group.

In this regard, the collaboration with the Extremadura School presented us with an opportunity to reflect on the socialising function of education and the need to contribute to the achievement of an inclusive school that welcomes cognitive, economic, social and other differences. The following extract from the teaching report includes the prioritisation of actions to promote the questioning of schooling under equal conditions.

"Empowering ourselves from the recognition of otherness"

We believe it is important that children understand the reality in which they are immersed and don't dress it up with false images. That is, the subjects proposed earlier [socioeconomic realities, cultural differences, etc.] must be treated with the sincerity required to create critical students conscious of the reality surrounding them; becoming aware of the situation of childhood in the world (...) To do this we suggest they produce a poster with the different places in the world where conditions of access and permanence in schools are not fulfilled, followed by an analysis of this (UT3_D3; stories, 2015).

The generation of links and the climate of trust inherent in the established pedagogical relationship encourage the identification of stereotypes and prejudices that would otherwise not have been detected because they would not have been able to transfer the private sphere of thought of the students. As a result of achieving this working environment we have been able to record how some stereotypes about violence and racism persisted despite knowledge built on diversity throughout the subject:

Maybe the mistake was the image of the school I created; to what extent is it useful to have informed them about the characteristics of the neighbourhood. It's like this information has contributed to creating certain prejudices; I realised their stereotypes when one of my students said: Let's collect everything before the school students come... something could be stolen (UT2_D3; stories, 2015).

In this regard, we can explain the incoherences of a theoretical discourse built on the foundations of an educational experience rooted in the exclusion of differences, in segregation by groups, in the stories that run parallel based on the social stratum of belonging, to be able to combat the perpetuation of stigmas and labels based on social groups. 
We conclude this analysis highlighting the valuations shown in the evaluation sessions. The voices of the students and participating teachers reflect the main transformations and dilemmas perceived in the improvement of collaboration and the pedagogical relationship as well as the advances in awareness about educational and social activism.

"An essential and professional experience"

Firstly, it is essential because it has allowed us to know other realities and be aware of how lucky or unlucky we are (UT2_D3; stories, 2015).

It has been important for my students, to continue their studies and believe in education as a way of getting out of their situation and transforming their lives (...) You had to see how they related to one another (ST2_D3; interview, 2015).

We talk about inclusion, dreams and how these dreams can turn into reality, becoming what you want (US_D3; discussion group, 2015).

According to the prompts from stories, interviews and discussion groups, this experience has allowed university students to be aware of other realities and circumstances which are different, more restricted and difficult than ours. At the same time, university students learnt to respect the children's behaviour, individuality and their ability to work.

\section{DISCUSSION}

The analysis carried out has enabled us to reconsider university classrooms as scenarios capable of encouraging the construction of different narratives through these "universityschool" shared meetings within the context of an interuniversity project. The different stories include the reinvention of work scenarios which are usually institutionalised, subject to closed formulas for teaching subjects in which practices are developed over a fragmented schedule which impedes the connection between subjects; it is infrequent and anecdotal for schools to visit and develop experiences stimulated by university students (Sanz \& Gutiérrez, 2016).

The results show the transformations of the protagonists of the experience and of those who participated indirectly, redefining personal stories in the context of collaborative work, given that our teaching identity is shaped by recounting our experiences and the stories that others narrate about us (Clandinin \& Connelly, 2004), thereby contributing to the improvement of our professional development (Adams, 2017; Sfard \& Prusak, 2005).

Essentially, this research has been developed facilitating communication and exchange between university students immersed in the experience about what has been learned and similarly between the teaching staff, contemplating a design in which classrooms become open, shared and adaptable spaces, redefining ourselves listening to the needs of the agents with whom we work (Cook, 2015; Nind, 2014). It is precisely this transformation of the design that has enabled horizontality in the collaboration process and in the pedagogical relationship that has been established, since it is the students who design and manage 
these shared spaces, making themselves the real protagonists of the devised learning situations (Niemi, 2002).

On the one hand, the university-school encounters have increased the responsibility of our students with regard to the participating children from Primary schools. Furthermore, University-School collaboration allows university students to participate in the design of the activities and workshops, the management of time and resources as well as follow-up assessment activities in a specific and contextualised learning situation (Lave \& Wenger, 1991). In this regard, the research role of students in the university context and their participation in the review of the teaching process has been enhanced, integrating their voice in reflection on improvement.

On the other hand, it would also benefit schools because of the opportunity that it offers them to familiarise themselves with the university as an institution and carry out educational experiences in a different environment to the one in which the school students usually study. Through the workshops, it has been possible to explain many labels, which are assumed unconsciously and encourage the questioning of preconceived ideas as a way of overcoming stereotypes. The analysis of the stories allows us to show how the workshops' context has enabled the generation of a neutral space, overcoming the barriers of the school environment and impediments to achieving curricular development according to an inclusive model (Ainscow, 2005) which welcomes ethnic, cognitive, cultural, socio-economic and gender differences, among others (Abdallah, 2017).

The results of the research show the implications of an interuniversity project whose relevance lies in promoting the transformation of scenarios which are usually isolated, in which the teaching of subjects is normally developed in the context of initial training, recounting the richness inherent in the mixture of geographical and cultural contexts involved (Pence \& Macgillivray, 2008). In addition the dilemmas and critical incidents allow us to plan the next cycle of action as we will explain in the following section.

\section{CONCLUSIONS}

The deconstruction of the research process from a narrative approach has enabled us to open a space for reflecting on the actions that promote participation and exchange between students at different levels of university education, encouraging links with schools. The findings and limitations will now be summarised, taking into account the objective of the research and the issues which have guided the inquiry process.

The results presented in this paper demonstrate the progress made in this phase and the crystallisation of our commitment to improving interrelationships between agents and contexts, encouraging the presence of schools in university contexts. We have managed to break away from the normal isolation of the classroom and expand, challenging the established academic system which presides in university teaching (Alonso \& Berasategi, 2017; M. \& Dubula, 2016). From the story of the actions linked to the design, development and assessment of the workshops we have been able to identify the meanings that are being reconstructed in the process of collaboration itself. This opening of university contexts to accom- 
modate school students has allowed closer relationships between the agents involved and signified the beginning of a long journey towards the dream of expanded education (Díaz, Lamb, Wesch, Ito, \& Gil, 2012). We have approached the use of different languages and media in order to understand the diversity of situations as an enriching element, concerning ourselves with achieving a climate of trust and respect between participants. In contrast to establishing an instrumentalised relationship, we have laid the foundations for continuous progress in a process of shared creation of knowledge in a horizontal and reciprocal way (Edward-Groves \& Kemmis, 2016).

The bibliographical review with regard to the use of narrative techniques has enabled us to methodologically redirect the design of our research, opening channels for analysing and describing the collaboration experience we have had. Thus, we have been able to identify the improvements which have been implemented both in relation to the establishment of links with schools and in the pedagogical relationship with our university students, to avoid vertical directionality in the design of the learning situations, increase the link between theory and educational practice and allow them to experience the role of teacher researcher in a university context, through reflection on action (Price, 2001).

\section{IMPLICATIONS}

Nevertheless, we have also identified a number of gaps and difficulties which we will use to guide the introduction of improvements in the next cycle of collaboration (Harrison, 2013). Some of these arise from the difficulties found with respect to the university students related to stereotypical attitudes or beliefs that we have detected among them or the lack of knowledge regarding the Primary school students who participated in the experience. We believe that these issues need to be addressed in university classrooms beforehand, through an analysis of the context to enable us to anticipate and critically analyse expectations of the characteristics of students, the socialising function of education, situations of exclusion and student failure (Alexander, Entwisle, \& Kabbani, 2001; Drescher, 2017; Li, Kenzy, Underwood, \& Severson, 2015; Stosich, 2016).

Another improvement is related to the need to study in-depth the role that universities can play in building Knowledge democracy. We have to reconsider how we can provoke transformation and break away from inertias in order to promote, on the contrary, honesty, transparency and coherence in this teaching model, something which must be adapted to a society in constant change. This involves questioning how universities promote teaching and which teaching model it generates, that is, we need to think about the social, political and ethical dimension of universities (Giroux, 2016; Jordan \& Kapoor, 2016; Rowell \& Hong, 2017; Sousa, 2006).

In this regard, we consider creating situations in which we can deconstruct school experiences in order to unlearn the internalised teaching model to be a priority since it involves deeply rooted knowledge, experienced during the time we spend at school. In order to do this, we intend to incorporate reflection on students' school and life stories with the obje 
ctive of being able to question the teaching model and the functioning of schools in order to explore the conflicts and contradictions in the reconstruction of knowledge (Bruner, 1986). Likewise, the work carried out with regard to the school biographies will enable us to generate learning situations which question the representations of otherness constructed from hegemonic cultures that mediate our understanding and interaction with minority groups (Beberley, 2010).

Finally, we believe that it is necessary to continue looking further into the resonances that can provoke this process of collaboration in other university groups, the participation of external agents as evaluators of the process, the role of the visual narratives and the reuse of materials generated to facilitate remixing in their use (Wiley, 2007).

\section{REFERENCES}

Abdallah, M. M. S. (2017). Towards improving content and instruction of the 'TESOL/TEFL for Special Needs' course: an action research study. Educational Action Research, 25(3), 420-437. https://doi.org/10.1080/09650792.2016.1173567

Adams, G. (2017). Using a narrative approach to illuminate teacher professional learning in an era of accountability. Teaching and Teacher Education, 67, 161-170. https://doi.org/10.1016/ j.tate.2017.06.007

Ainscow, M. (2005). Developing inclusive education systems: what are the levers for change? Journal of Educational Change, 6, 109-124. https://doi.org/10.1007/s10833-005-1298-4

Alexander, K. L., Entwisle, D. R., \& Kabbani, N. (2001). The Dropout Process in Life Course Perspective: Early Risk Factors at Home and School. Teachers College Record, 103(5), 760-822. https://doi.org/10.1111/0161-4681.00134

Alonso, I., \& Berasategi, N. (2017). The integrated curriculum, university teacher identity and teaching culture: the effects of an interdisciplinary activity. Journal of New Approaches in Educational Research, 6, 127-134. https://doi.org/10.7821/naer.2017.7.235

Anderson, G. (2017). Participatory Action Research (PAR) as Democratic Disruption: New Public Management and Educational Research in Schools and Universities. International Journal of Qualitative Studies in Education, 30(5), 432-449. https://doi.org/10.1080/09518398.2017 .1303211

Arvanitakis, J., \& Hornsby, D. J. (2016). Universities, the citizen scholar and the future of higher education. Hampshire: Palgrave Macmillan. https://doi.org/10.1057/9781137538697

Beberley, J. (2010). Theses on subalternity, representation, and politics. Postcolonial Studies, 1(3), 305-319. https://doi.org/10.1080/13688799889987

Brown, M. (2008). Comfort zone: Model or metaphor? Australian Journal of Outdoor Education, 12(1), 3-12. https://doi.org/10.1007/BF03401019

Bruner, J. (1986). Actual minds, possible worlds. Cambridge: Harvard.

Clandinin, D. J. (2013). Engaging in narrative inquiry. Walnut: Creek, Cal: Left Coast Press.

Clandinin, D. J., \& Connelly, F. M. (1991). Narrative and story in practice and research. In C. Witherell \& N. Noddings (Eds.), Stories lives tell: Narrative and dialogue in education (pp. 259-281). New York: Teachers College.

Clandinin, D. J., \& Connelly, F. M. (2004). Narrative inquiry: Experience and story in qualitative research. San Francisco: Jossey-Bass.

Cochram-Smith, M., \& Little, S. L. (1993). Inside/outside. Teacher research and knowledge. New York: Teachers College Press. 
COM. (2007). Improving the Quality of Teacher Education. Communication from the Commission to the Council and the European Parliament. Retrieved from Retrievedfromhttp://eur-lex.europa .eu/legal-content/EN/TXT/?uri=celex:52007DC0392

Cook, T. (2015). Harnessing the power and impact of creative disruption. Educational Action Research, 23(4), 461-464. https://doi.org/10.1080/09650792.2015.1099977

Corbin, J., \& Strauss, A. (2008). Basics of Qualitative Research: Techniques and Procedures for Developing Grounded Theory. Thousand Oaks, CA: Sage. https://doi.org/10.4135/9781452230153

Cortés, P., Rivas, J. I., \& Leite, A. (2016). Education and social change in Spain: from crisis to opportunity. Ethnography and Education, 11(2), 204-221. https://doi.org/10.1080/17457823 .2016.1147971

Darling-Hammond, L., Pacheco, A., Michelli, N., LePage, P., Hammerness, K., \& Youngs, P. (2005). Implementing Curriculum Renewal in Teacher Education: Managing Organizational and Policy Change. In L. Darling-Hammond \& J. Bransford (Eds.), Implementing Curriculum Renewal in Teacher Education: Managing Organizational and Policy Change (pp. 442-478). San Francisco: Jossey-Bass.

De Oliveira, J., \& Gallardo-Echenique, E. (2015). Early Childhood Student Teachers' Observation and Experimentation of Creative Practices as a Design Processes. Journal of New Approaches in Educational Research, 77-83. https://doi.org/10.7821/naer.2015.4.122

Díaz, R., Lamb, B., Wesch, M., Ito, M., \& Gil, F. G. (2012). Expanded Education. Retrieved from http://www.international.zemos98.orgIMG/pdf/expanded_education.pdf

Drescher, T. (2017). The Potential of Modelling Co-Teaching in Pre-Service. Education, Journal of University Teaching \& Learning Practice, 14(3). Retrieved from http://ro.uow.edu.au/cgi/ viewcontent.cgi?article $=1764 \&$ context $=$ jutlp

Edward-Groves, C., \& Kemmis, S. (2016). Pedagogy, education and praxis: understanding new forms of intersubjectivity through action research and practice theory. Educational Action Research, 24(1), 177-97. https://doi.org/10.1080/09650792.2015.1076730

Fernández-Díaz, E., Fernández-Olaskoaga, L., \& Gutiérrez-Esteban, P. (2017). Collaborative Action Research through technologically mediated agoras. Educational Action Research, 25(1), 56-70. https://doi.org/10.1080/09650792.2016.1141107

Forés, A., Sanchez-Valero, J. A., \& Sancho, J. M. (2015). Leaving comfort zone. Dilemmas and challenges in the European Higher Education Space. Tendencias Pedagógicas [Pedagogical Tendences], 23, 205-214. Retrieved from https://revistas.uam.es/tendenciaspedagogicas/article/ view/2080/2178

Fouche, C. B., \& Chubb, L. A. (2015). Action researchers encountering ethical review: a literature synthesis on challenges and strategies. Educational Action Research, 25(1), 23-34. https:// doi.org/10.1080/09650792.2015.1128956

Frymier, A., \& Houser, M. (2000). The teacher student relationship as interpersonal Relationship. Communication Education, 58(3), 327-349. https://doi.org/10.1080/03634520009379209

Gardner, H. (1983). Frames of mind: The theory of multiple intelligences. New York: Basic books.

Giroux, E. (2016). Higher Education and the politics of disruption. Entramados, Educación y Sociedad, [Frameworks: Education and Society], 3, 15-26. Retrieved from http://fh.mdp.edu .ar/revistas/index.php/entramados/article/view/1615/1614

Hansen, D. T. (2014). Cosmopolitanism as cultural creativity: New modes of educational practice in globalizing times. Curriculum Inquiry, 44(1), 1-14. https://doi.org/10.1111/curi.12039

Harrison, C. (2013). Collaborative action research as a tool for generating formative feedback on teachers' classroom assessment practice: The KREST project. Teachers and Teaching: Theory and Practice, 19(2), 202-213. https://doi.org/10.1080/13540602.2013.741839

Hernández-Hernández, F., \& Sancho, J. M. (2017). Life histories and narratives about subalternity: 
Facing the challenge of the intractable in relation with the other. Educar, 54(1), 15-29. https:// doi.org/10.5565/rev/educar.913

Jordan, S., \& Kapoor, D. (2016). Re-politicizing participatory action research: unmasking neoliberalism and the illusions of participation. Educational Action Research, 24(1), 134-150. https://doi.org/10.1080/09650792.2015.1105145

Kemmis, S., \& McTaggart, R. (2013). Participatory action research. Communicative action and the public sphere. In N. Denzin \& Y. Lincoln (Eds.), Handbook of qualitative research (pp. 271-328). Thousand Oaks, CA: Sage.

Lafuente, A., \& Lara, T. (2013). Situated learning and practices procomunals. RASE Journal, 6(2), $168-177$.

Lave, J., \& Wenger, E. (1991). Situated learning: Legitimate peripheral participation. Cambridge: Cambridge University Press. https://doi.org/10.1017/CBO9780511815355

Li, X., Kenzy, P., Underwood, L., \& Severson, L. (2015). Dramatic Impact of Action Research of Arts-Based Teaching on At-Risk Students. Educational Action Research, 23(4), 567-580. https://doi.org/10.1080/09650792.2015.1042983

M., A., \& Dubula, V. (2016). Walking the Walk? Critical reflections from an Afro-Irish emancipatory research network. Educational Action Research, 24(1), 115-134. https://doi.org/10.1080/ 09650792.2015.1132242

Margalef, R., \& Pareja, L. (2008). Innovation, Research and Professional Development in Higher Education: Learning from Our Own Experience. Teaching and Teacher Education, 24(1), 104116. https://doi.org/10.1016/j.tate.2007.03.007

McFadden, A., \& Smeaton, K. (2017). Amplifying Student Learning through Volunteering. Journal of University Teaching \& Learning Practice, 14(3). Retrieved from http://ro.uow.edu.au/cgi/ viewcontent.cgi?article $=1710 \&$ context $=$ jutlp

Miles, M., \& Huberman, A. M. (1994). Data management and analysis methods. In N. K. Denzin \& Y. S. Lincoln (Eds.), Handbook of qualitative research (pp. 429-444). London: Sage Publication.

Ng, W., Nicholas, H., \& Williams, A. (2010). School experience influences on pre-service teachers' evolving beliefs about effective teaching. Teaching and Teacher Education, 26, 278-289. https:// doi.org/10.1016/j.tate.2009.03.010

Niemi, H. (2002). Active learning: a cultural change needed in teacher education and schools. Teaching and Teacher Education, 18, 763-780. https://doi.org/10.1016/S0742-051X(02)00042 $-2$

Nind, M. (2014). What is inclusive research? London/New York: Bloomsbury Publishing.

Patton, K., \& Parker, M. (2017). Teacher education communities of practice: More than a culture of collaboration. Teaching and Teacher Education, 67, 351-360. https://doi.org/10.1016/j.tate .2017.06.013

Pence, H. M., \& Macgillivray, I. K. (2008). The Impact of an International Field Experience on Preservice Teachers. Teaching and Teacher Education, 24(1), 14-25. https://doi.org/10.1016/ j.tate.2007.01.003

Price, J. (2001). Action research, pedagogy and change: The transformative potential of Action research in preservice teacher education. Curriculum Studies, 33(1), 43-74. https://doi.org/ $10.1080 / 00220270118039$

Rice, E. H. (2002). The Collaboration Process in Professional Development Schools. Results of a Meta-Ethnography, 1990-1998. Journal of Teacher Education, 53(1), 55-67. https://doi.org/ $10.1177 / 0022487102053001006$

Rivas, J. I. (2014). New identity in teacher education: students' voices. International Journal of Development and Educational Psychology, 7(1), 487-494. Retrieved from http://www.infad 
.eu/RevistaINFAD/OJS/index.php/IJODAEP/issue/view/16

Rivas, J. I., Leite, A. E., Márquez, M. J., Cortés, P., Prados, M. E., \& Padua, D. (2016). Facebook as a virtual place to share learning between groups of students from different universities. RELATEC, Latin American Journal of Educational Technology, 15(2), 55-66.

Rowell, L. L., \& Hong, E. (2017). Knowledge democracy and action research: Pathways for the Twenty-First Century. In L. L. Rowell, C. D. Bruce, J. M. Shosh, \& M. M. Riel (Eds.), The Palgrave International Handbook of Action Research (pp. 63-83). New York: Palgrave Macmillan. https://doi.org/10.1057/978-1-137-40523-4_5

Sancho, J., \& Padilla, P. (2016). Promoting digital competence in secondary education: are schools there? Insights from a case study. Journal of New Approaches in Educational Research, 5(1), 57-63. https://doi.org/10.7821/naer.2016.1.157

Sanz, J., \& Gutiérrez, L. (2016). Scientific workshops with children in the early childhood education degree: a model of action research and a university-school initiative. Campo Abierto [Open Field Journal], 35(1), 205-216. Retrieved from http://mascvuex.unex.es/revistas/index.php/ campoabierto/article/view/2844

Schiro, M. S. (2008). Curriculum Theory: Conflicting Visions and Enduring Concerns. Los Angeles, CA: Sage.

Sfard, A., \& Prusak, A. (2005). Telling identities: In search of an analytic tool for investigating learning as a culturally shaped activity. Educational Researcher, 34, 14-22. https://doi.org/ 10.3102/0013189X034004014

Sousa, B. (2006). The university in the 21 st century: Toward a democratic and emancipatory university reform. In R. A. Rhoads \& C. A. Torres (Eds.), The university, state, and market: The political economy of globalization in The Americas (pp. 60-100). Palo Alto: Stanford University Press.

Sparkes, A. C., \& Smith, B. (2008). Narrative constructionist inquiry. In J. Holstein \& J. Gubrium (Eds.), Handbook of constructionist research (pp. 295-314). London: Guilford Publications.

Stosich, E. I. (2016). Building teacher and school capacity to teach to ambitious standards in highpoverty schools. Teaching and Teacher Education, 58, 43-53. https://doi.org/10.1016/j.tate .2016.04.010

Sutherland, L. M., Howard, S., \& Markauskaite, L. (2010). Professional identity creation: Examining the development of beginning preservice teachers' understanding of their work as teachers. Teaching and Teacher Education, 26(3), 455-465. https://doi.org/10.1016/j.tate.2009.06.006

Thomson, P. (2015). Action Research with/against Impact. Educational Action Research, 23(3), 309-311. https://doi.org/10.1080/09650792.2015.1062235

Wiley, D. (2007). On the sustainability of open educational resource. Initiatives in Higher Education. OECD's Centre for Educational Research and Innovation (CERI). OECD Publishing. Retrieved from https://www.oecd.org/edu/ceri/38645447.pdf

Young, I. M. (2000). Inclusion and Democracy. Oxford: Oxford University Press.

Zeichner, K., \& Conklin, H. (2008). Teacher education programs as sites for teacher preparation. In M. Cochran-Smith, S. Feiman-Nemser, \& D. J. McIntyre (Eds.), Handbook of Research on Teacher Education. Enduring Questions in Changing Contexts (pp. 269-289). New York: Routledge. 